\title{
Case Method in Vocational Training for Future Specialists of Culture and Art
}

\author{
Alexey Pavlovich Efremenko ${ }^{1, *}$, Dmitry Aleksandrovich Berezhnoy ${ }^{1}$, Aleksandr Petrovich Tsilinko ${ }^{1}$, \\ Tatiana Aleksandrovna Lomakina', Alla Ivanovna Solovey ${ }^{2}$ \\ ${ }^{1}$ Department of Arts and Artistic Creation, Russian State Social University, Moscow, Russia \\ ${ }^{2}$ Department of Orchestra Art, Moscow State Institute of Music named after A.G. Schnittke, Russia
}

Received April 6, 2020 ; Revised July 6, 2020; Accepted July 20, 2020

\section{Cite This Paper in the following Citation Styles}

(a): [1] Alexey Pavlovich Efremenko, Dmitry Aleksandrovich Berezhnoy, Aleksandr Petrovich Tsilinko, Tatiana Aleksandrovna Lomakina, Alla Ivanovna Solovey, "Case Method in Vocational Training for Future Specialists of Culture and Art," Universal Journal of Educational Research, Vol. 8, No. 9, pp. 3793 - 3798, 2020. DOI: 10.13189/ujer.2020.080901.

(b): Alexey Pavlovich Efremenko, Dmitry Aleksandrovich Berezhnoy, Aleksandr Petrovich Tsilinko, Tatiana Aleksandrovna Lomakina, Alla Ivanovna Solovey (2020). Case Method in Vocational Training for Future Specialists of Culture and Art. Universal Journal of Educational Research, 8(9), 3793 - 3798. DOI: 10.13189/ujer.2020.080901.

Copyright $\bigcirc 2020$ by authors, all rights reserved. Authors agree that this article remains permanently open access under the terms of the Creative Commons Attribution License 4.0 International License

Abstract Today, the priority task of the higher education institution in the artistic specialty is to prepare a future specialist in the Folk-Art Culture, capable of carrying out creative and innovative activities at a high professional level. One of the effective methods of teaching the humanities is the case study method, but its applicability in the training of cultural and art workers requires adequate research. The study is aimed at evaluating the effectiveness of the case method when training in the Folk-Art Culture specialty. The study used a complex of theoretical (analysis of scientific literature and pedagogical experience in related fields of pedagogy) and empirical (pedagogical experiment) research methods. The article considers the application of the case method in the preparation of specialists in arts and culture and describes several cases applied in the process of mastering folk culture. Results of the research on the influence of the case method on the educational process allow the authors to say that the case method, aimed at independent knowledge acquisition by students, provides for the education of comprehensively developed, responsible, and thinking persons. The main task of a modern educator is to select educational technology adequate to the specialty, forming students' analytical skills, as well as their ability to independently acquire knowledge, apply it in problem-solving, and make a choice in a non-standard situation. The main conclusion of the research is that due to its versatility, the case method can be adapted to the educational process in arts and culture universities at different educational stages.

Keywords Innovative Method, Educational Technology, Professional Preparation, Case Method, Music Theory

\section{Introduction}

In order to implement the competency-based approach in Russian education, active forms of classes are preferred in the educational process since competencies are aimed at the implementation of professional functions and manifested only in activity [1]. Thus, in the modern education system, the focus is on the mastering activity and new educational technology [2].

The case method, like developmental education, "is aimed at learning not only facts but also the relationships between them, establishing cause and effect relationships, and turning the relationships into the study object" [3, p. 272]. According to specialists, "Case study is a promising and productive method in the education of future educators since theory in this field is only valuable in its relation to practical activity" [4]. In the modern education system, it has proved to be "one of the most effective teaching 
methods in general and special classes, as well as distance learning” [5, p. 62]. It provides a "high level of education when knowledge, abilities, and skills become an immanent trait of a university graduate's personality” [2, p. 159].

The case method develops analytical thinking, initiates independent analysis of a situation and searches for its solution by students themselves, and forms their ability to converse, debate, and take responsibility for their choices. It can "minimize the distance between theory and practice" and "consolidate acquired knowledge through the prism of a case and readiness for independent practical work" [6, p. 226]. Since the effectiveness of this method in other fields has been confirmed by years of practice, it could be of use in the humanities as well. "The application of the case method optimizes the educational process and allows better comprehending material, as well as increasing students' interest in the study of a discipline” [7, p. 192].

In this article, the study of the case method effectiveness in training the Folk-Art Culture specialty, the purpose of which is to preserve ethnic identity and establish inter-ethnic relations, is carried out. In this connection, students studying in the Folk-Art Culture specialty pay much attention to the study of ethnographic and cultural disciplines, ethnopsychology; they study the cultural heritage of the people, participate in ethnographic expeditions; they learn how to organize the activities of children's and adult artistic and ethnographic groups, conduct choreographic and vocal classes, which generally contribute to the preservation and enhancement of the cultural heritage of the country, and form a public opinion regarding the folk-art culture and traditional values of the people. The Folk-Art Culture specialty has become the totality of a number of humanities, turning into an effective tool for studying cultural heritage and specific art forms.

In the authors' opinion, the use of the case study method will allow the formation of the necessary professional competencies among students of the Folk-Art Culture specialty and will bring training material closer to their future activities.

Working with a case, as noted by O.G. Tolochina, “includes the following stages: students' independent individual work with case materials (problem identification, formulation of key alternatives, the proposal of a solution or recommended action); work in small groups on the development of the vision of the key problem and its solutions; presentation and expertise of small groups' results at a general discussion (in the study group)" [8]. Tolochina distinguishes introductory, informational, strategic, research, and training cases.

A comprehensive study of the case method allows classifying cases based on certain criteria. Thus, M.Kh. Khaibulaev and G.M. Gadzhikurbanova classify cases based on structure, size, presentation method, etc. [9].

Currently, the use of the case method is becoming more widespread in the teaching of the humanities $[10 ; 11]$; however, insufficient knowledge of its application in the training of cultural and art workers, including of the
Folk-Art Culture specialty, allows talking about the relevance of the study.

\section{Methods}

The purpose of the study is to evaluate the effectiveness of the case method when studying in the Folk-Art Culture specialty.

A complex of theoretical and empirical research methods was used in the study:

- $\quad$ theoretical methods - analysis of scientific literature and pedagogical experience in related fields of pedagogy;

- empirical methods - a pedagogical experiment, consisting of diagnostic (ascertaining), formative, and control stages.

In total, 67 students enrolled in the Folk-Art Culture specialty were involved in the experiment.

At the diagnostic stage, a survey was conducted, in which students were asked whether they liked the subject they were studying, methods of information presentation, forms of classes, and tasks for independent work and how well they acquired new knowledge and professional skills.

Also, respondents were asked to evaluate the quality of educational services provided by the Alfred Nobel University on a scale of 2 to 5 , where 5 was fully satisfied; 4 - satisfied to some extent; 3 - not fully satisfied; 2 - not satisfied.

At the formative stage of the experiment, specific case studies were developed and introduced into the process of training specialists in culture and art. Here are a few examples of cases developed specifically for future folk culture specialists.

Case 1. Reproducing a folk song by ear to develop the style and expand the repertoire. Case: During one of the folklore expeditions, a song of rare beauty was recorded. Its musical recording does not exist but it perfectly complements the program of the planned concert of folk music. Students need to restore the whole picture - a folk song and dance piece with all its attributes. For this, the students have to conduct educational, research, artistic, and creative activities.

To understand what movements would be appropriate in the performance of this song, the students listen to the recording and determine the region of origin based on the melodic, singing, intonational, rhythmic, genre, and stylistic features, as well as the manner of performance. Thus, the students deeply comprehend the material with which they will deal with their work with folk groups. Then, in scientific literature, anthologies, and other sources, the students find descriptions related to the dance movements, costumes, and nature of the performance - in other words, create a common context for solving the task. The result is a learned song and its musical notation. An incentive for the students may be the educator's suggestion that this song 
could be an exclusive concert number of the group. The motivation will be the proposal not only to learn the song but also to save it for future generations, for example, analyzing it in a scientific article and publishing as a musical example.

Case 2. Restoring the sequence of the wedding ceremony in the villages of the Vologda region. Case: There are few participants in the old Russian rite left in the village. To preserve it, folklorists recreate the tradition from individual memoirs, materials, and sources. Students are given the task to determine the sequence of stages in the wedding ceremony. They include: after the nuptials; feast at the bride's house; matchmaking; guarantee; final wedding ceremonies; inspection of the place; beer-brewing; departure for the nuptials; first week; bringing to the table; nuptial day morning; the arrival of the groom during the week; bathing; hen party; wedding day morning; bringing of the bride to the table; meeting with bridesmaids; greeting; the arrival of the groom [12]. All stages of the wedding in the Vologda region are reflected in descriptions, illustrations, images of clothes and household items, as well as objects of applied art.

To solve this problem, the educator, together with the students, studies scientific literature, memories of living witnesses of old events, photographs, video and audio recordings of folk tunes, and other sources of information. Using the knowledge gained earlier and following the logic of thinking, analyzing and summarizing the data, during the discussion, the students determine the sequence of events, lay out available illustrations in the correct order, and select appropriate tunes for each stage.

Case 3. Identifying the rite and region using photographs or sketches of costumes. Case: To participate in a competition, it is necessary to prepare and present to the audience and the jury members a ritual that is either little known among professionals or seemed to be irretrievably lost. Students' task is to restore the full picture of this rite from its meaning to the region of its origin.

The students analyze the situation in detail. Studying photographs and illustrations, they describe the season, people's actions, nature of events, objects used, and possible meaning of the rite and, based on the costumes, determine the region where the photos were taken.

After applying the case method, a control experiment was conducted, which included a resurvey of students in which the questions were asked about whether students liked the subject studied, methods of presenting information, classes and tasks for independent work, how well new knowledge was acquired, and professional knowledge and skills were mastered.

\section{Results}

The diagnostic phase of the study showed the following results.

To the first question of the questionnaire "Are you satisfied that you are studying the chosen specialty?", the following answers were given: 44 survey participants $(65.7 \%)$ were satisfied that they were studying the chosen specialty, 23 future bachelors (34.3\%) were partially satisfied.

Applicants for higher education and bachelor's degree in Folk-Art Culture specialty evaluated the effectiveness of the methods and teaching methods that were used in the program, as well as their stimulation to self-education and research activities. The proposed statements could be evaluated on the following scale: 3 - I definitely agree; 2 - I basically agree; 1 - I completely disagree; 0 - I find it difficult to answer.

Regarding the statement, "Teaching and learning methods are effective for this program”, 40 respondents (59.7\%) rated teaching and learning methods as effective, 27 respondents (40.3\%) did not agree that the methods used during teaching and learning were effective.

Regarding satisfaction with the teaching process (statement "I am satisfied with the teaching"), 39 respondents (58.2\%) were satisfied with the teaching, 28 respondents (41.8\%) were not satisfied with the teaching.

Regarding the statement "The program stimulates self-education”, 24 survey participants (35.8\%) agreed that the educational program stimulated them to self-education; 43 respondents $(64.2 \%)$ did not agree that the program stimulated self-education.

Regarding the statement "The program stimulates research activities”, 17 respondents (25.4\%) noted that training stimulated them to research activities, 30 respondents (44.8\%) did not agree with this statement, another 20 respondents (29.8\%) stated that it was difficult for them to answer this question. Thus, $75 \%$ of respondents believed that training did not stimulate them to research activities.

The results of assessing the quality of educational services are presented in Table 1.

Table 1. Assessment of the educational services quality

\begin{tabular}{|c|c|}
\hline Answer options & Survey results \\
\hline 5 - fully satisfied & 17 respondents $(25,4 \%)$ \\
\hline 4 -satisfied to some extent & 33 respondents $(49,3 \%)$ \\
\hline 3 - not fully satisfied & 16 respondents $(23,9 \%)$ \\
\hline $2-$ not satisfied & 1 respondent $(1,4 \%)$ \\
\hline
\end{tabular}

Thus, according to the survey results, $74.7 \%$ (50 respondents) of the survey participants were satisfied with the quality of the educational services provided by the university; 23.9\% (16 respondents) were not fully satisfied, one future specialist (1.4\%) was not satisfied with the educational services quality.

Thus, the results of the survey at the ascertaining stage of the experiment demonstrated that students showed insufficient interest in subjects of the professional unit, teaching methods and forms of presentation of information, and the tasks seemed boring and of little use to them; 
besides, according to students, they did not stimulate self-education and research activities.

In this regard, at the formative stage of the experiment, it was decided to develop and introduce specific case studies into the training of cultural and art specialists.

Resurvey of students at the control stage of the experiment showed an increase in students' satisfaction with the chosen specialty and the teaching process, higher assessment by students of the effectiveness of teaching and learning methods. According to the respondents, the implementation of the case method in the learning process stimulated them to self-education and research activities.

\section{Discussion}

As the results of a theoretical study have shown, for courses related to the Folk Culture specialty, the most useful are training, practice, research, demonstration, and innovative (by the degree of influence of the main sources), plot and plotless (by the presence of the plot), story, presentation, essay, illustration, and practical task (by genre), complex (modular), and other types of cases [13-17]. The content of the cases was diverse and depended on the formed competencies, specialty, and tasks set by the educator.

The students' task was to create a comprehensive picture based on individual facts and events and to find the main "purpose" of this picture. "Students familiarize themselves with the case, study it, and, together with the educator, begin a detailed discussion of its content to find the optimal (or several equally possible) solutions. Moreover, a case (as a set of written assignments) can be represented/replaced by a real assignment offered to students" [6, p. 237]. The main condition of the method "is the existence of contradictions, based on which, problem situations, assignment, and practical tasks for discussion and optimal solution by students are formed and formulated” [18, p. 297]. Contradictions lead students to a state of difficulty, raise questions, and force them to seek solutions, activating their independent cognitive and research activities.

The role of the educator applying the case method is not only to prepare a set of materials and coordinate the process of the development of students' knowledge and practical skills. The educator synthesizes the functions of education, upbringing, organization, and research management. The first part of the educator's work creative (case preparation) - includes research, methodological, and organizational activities. The second part - the successful conduct of the class - depends on the general professional training of the specialist and their pedagogical talent. They "give introductory and concluding speeches, organize small groups and discussion, support the business spirit in the audience, and evaluate the contribution of students to the analysis of the situation" [19, p. 250].
It is noteworthy that the case method was originally developed for the sciences related to economics and business at the Harvard Business School (1924). However, in recent years, it has been widely used in courses related to arts. Thus, N.N. Mokrushina writes, "The case technology is most successfully applied in those disciplines, in which there is no unequivocal answer to a cognitive question but several answers that can compete in terms of the degree of truth. As a result, the educational process from a simple transfer of knowledge and skills from the educator to the student turns into the gradual formation of a certain attitude and style of behavior in each specific situation" [20].

A comparison of the results of our pedagogical experiment on the use of the case method in the training of arts and culture specialists with other studies reveals the specifics of case studies for humanities students. For students of arts and culture universities, some components of a case should be adapted to their specialty. Thus, in the training of future managers and specialists in folk culture, audio recordings and live performances of folk music are preferred, along with visual and illustrative materials. In our opinion, in cases related to the humanities, it is advisable not to present facts, provisions, and options to students in a finished form but to instruct them to find them in the main and additional literature. The mode of work with a case in the field of arts should also be adapted to the specialty and problem task.

The case method can be adapted to the educational process in art and culture universities due to its universality $[21,22]$ at different stages of professional preparation (studying at a university, checking results, exams, advanced training) and different methods of interaction between participants (open discussion, individual or group survey, role play, confrontation or cooperation, etc.). "It is used in vocational education because situational exercises offered to students can be created to master different professions" [19, p. 246]. The success of case study depends on its compliance with a clearly defined goal and objectives, the adequacy of its level of complexity to the capabilities of students, the relevance of the topic, national specifics, potential in the development of analytical thinking and the skill of scientific discussion, as well as the ability to solve complex, ambiguous problems and accept several solutions to the assignment.

\section{Conclusions}

Active learning creates positive motivation for learning, develops cognitive abilities, initiates and directs mental activity. Moreover, it integrates learning and upbringing processes due to the dialogical design of subject-object relationships, practical orientation, and group form of organization of classes, as well as joint problem solving and role distribution. However, the main advantage is the formation of responsibility for the results of teamwork. All 
these qualities necessary for future managers of creative teams, as well as many others, must be acquired at university, which means that the emphasis in the content of classes should fall on folk culture.

As practice shows, the case method is associated with an increased degree of motivation, emotionality, and creativity. The focus is not on the translation of ready-made knowledge but its independent development by students in the process of joint efforts, which allows educating a thinking person with significant creative potential necessary for modern society. The case method allows students to show creativity, independence, and competitiveness in the changing socio-economic conditions of today.

The significance of our findings compared to previous studies, as well as further research, lies in the fact that the case method has proved to be effective in the preparation of specialists in arts and culture. It helps build the students' analytical abilities and develop their ability to make responsible decisions in non-standard situations. It provides the development of key skills for a folk culture specialist related to teamwork and searches for information in various sources, its analysis and generalization, as well as the skills of presenting ideas, organizing work, and managing a group of people.

However, insufficient systematization and generalization of information and methodological materials, weak theoretical and methodological base, as well as unpreparedness of students for this form of training, make active research and application of the case method in the humanities difficult.

\section{REFERENCES}

[1] A. A. Kutumova. Keys-metod v formirovanii professionalnykh kompetentsiy [Case method in the formation of professional competencies], Problemy i perspektivy razvitiya obrazovaniya v Rossii, Vol. 28, 30-34, 2014.

[2] M. V. Pereverzeva, A. V. Smirnov. Sovremennoye solfedzhio kak usloviye formirovaniya professionalnykh kompetentsiy uchiteley muzyki [Modern solfeggio as a condition for the formation of professional competencies of music teachers], Uchenyye zapiski RGSU, Vol. 16, No. 5(144), 159-167, 2017.

[3] V. A. Sitarov. Didaktika [Didactics], Akademiya, Moscow, 2004.

[4] R. N. Valiullina. Keys-metod v kurse solfedzhio [The case method in the solfeggio course], Put nauki, Vol. 3, 96-98, 2016.

[5] B. Ye. Andyusev. Keys-metod kak instrument formirovaniya kompetentnostey [The case method as an instrument for forming competencies], Direktor shkoly, 4, 61-69, 2010.
[6] S. Nilova. Metod kysov v prepodavanii muzykalno-teoreticheskikh distsiplin [The case method in teaching theoretical musical disciplines]. Traditsii i novatorstvo v culture i iskusstve: svyaz vremen. Sb. st. po materialam II Vserossiyskoy nauchno-prakticheskoy konferentsii 21 marta 2014 goda [Tradition and innovation in arts and culture: the connection of times. Collection of articles based on the materials of the II All-Russian Scientific and Practical Conference March 21, 2014]. AIPKP, Astrakhan, 225-228, 2014.

[7] Ye. S. Zev. Keys-metod kak aktivnyy metod obucheniya v usloviyakh realizatsii FGOS SPO [Case method as an active learning method in the context of the implementation of the Federal State Educational Standard for Vocational Education]. Traditsii i novatorstvo $\mathrm{v}$ culture i iskusstve: svyaz vremen. Sb. st. po materialam II Vserossiyskoy nauchno-prakticheskoy konferentsii 21 marta 2014 goda [Tradition and innovation in arts and culture: the connection of times. Collection of articles based on the materials of the II All-Russian Scientific and Practical Conference March 21, 2014]. AIPKP, Astrakhan, 190-192, 2014.

[8] O. G. Tolochina. Keys-tekhnologii kak odin iz innovatsionnykh metodov obrazovatelnoy sredy [The case technology as one of the innovative methods of the educational environment]. Retrieved from https://nsportal.ru/vuz/pedagogicheskie-nauki/library/2013/ 01/22/keys-tekhnologii-kak-odin-iz-innovatsionnykh-metod ov

[9] M. Kh. Khaibulaev, G. M. Gadzhikurbanova. Primeneniye keys-metoda v nauchno-issledovatelskoy rabote budushchego pedagoga [Application of the case method in the research work of the future teacher]. Shkola, vuz: sovremennyye problema informatiki, matematiki i fiziki: materialy Vserossiyskoy nauchno-prakticheskoy konferentsii [School, university: modern problems of mathematics, computer science, and physics: materials of the All-Russian scientific-practical conference], Chechenskiy gos. ped. Universitet, Grozny, 181-186, 2013.

[10] V. I. Yekimova. Keys-metod v vasshey shkole: problem primeneniya i otsenki effektivnosti [Case study in higher education: problems of application and evaluation of effectiveness], Sovremennaya zarubezhnaya psikhologiya, Vol. 1, 86-97, 2014.

[11] O. G. Smolyaninova. Innovatsionnyye tekhnologii obucheniya studentov na osnove metoda CASE STUDY [Innovative educational technologies based on the case method], Innovatsii v rossiyskom obrazovanii: Sbornik statey [Innovations in Russian education: Collection of articles], MGUP, Moscow, 2000.

[12] D. M. Balashov, N. I. Kalmykova, Yu. I. Marchenko. Russkaya svadba: svadebnyy obryad na Verkhney i Ssredney Kokshenge i na Uftyuge [Russian wedding: the wedding ceremony in Upper and Middle Kokshenga and Uftyuga], Sovremennik, Moscow, 1985.

[13] M. V. Antipova. Metod keysov (case study). Metodicheskoye posobiye dlya prepodavateley filiala [The case study method. Toolkit for branch teachers]. Retrived from https://mpfmargtu.ucoz.ru/metod/metodicheskoe_poso bie-1.pdf

[14] Keys-metod. Okno v mir situatsionnoy metodiki obucheniya [The case method. The window to the world of situational 
teaching methods]. Retrieved from https://iphras.ru/ethics_c ase.htm

[15] S. V. Sazhneva, Ye. O. Kuzmenko. Keys-metod kak sovremennaya tekhnologiya professionalno orientirovannogo obucheniya studentov [The case method as a modern technology for professionally oriented student education]. Retireved from http://be5.biz/ekonomika1/r201 2/1907.htm.

[16] T. D. Strelnikova. Obucheniye s pomoshchyu keys-tekhnologiy [Study using the case technology], Spravochnik zamestitelya direktora, Vol. 4, 59-72, 2009.

[17] M. A. Kanayev, S. M. Mlakutskaya. Formirovaniye kompetentsyy ispolnitelskogo masterstva muzykanta $\mathrm{v}$ protsesse obucheniya igre na osnove kys-metoda [The formation of competencies in the performing skills of a musician in the process of learning to play based on the case method], Obrazovaniye i obshchestvo, Vol. 4, No. 87, 38-41, 2014.

[18] N. N. Sukhorukova. Keys-metod kak forma organizatsii samostoyatelnoy raboty studentov [The case method as a form of organization of student independent work]. Sovremennyye kontseptsii razvitiya nauki: Sb. st. mezhdunarodnoy nauchno-prakticheskoy konferentsii [Modern concepts of the development of science: Collection of articles of the International Scientific and Practical Conference], Aeterna, Moscow, 296-299, 2014.

[19] L. L. Filippova. Keys-metod kak sovremennaya tekhnologiya professionalnogo obucheniya [The case method as a modern technology of vocational training]. Psikhologiya i metodika: metodika i problemy prakticheskogo primeneniya, Tsentr razvitiya nauchnogo sotrudnichestva, Novosibirsk, Vol. 8, 246-250, 2009.

[20] N. N. Mokrushina. Keys-metod na urokakh muzyki v shkole: konspekt uroka muzyki v 6 klasse [The case method for music lessons at school: a music lesson in grade 6].

[21] T. K. Rostovskaya, A. S. Maksimova, N. M. Mekeko, S. N. Fomina. Barriers to Students' Academic Mobility in Russia, Universal Journal of Educational Research, Vol. 8, No. 4, 1218-1227, 2020.

[22] A. D. Matraeva, M. V. Rybakova, M. V. Vinichenko, A. A. Oseev, N. V. Ljapunova. Development of Creativity of Students in Higher Educational Institutions: Assessment of Students and Experts, Universal Journal of Educational Research, Vol. 8, No. 1, 8-16, 2020. 